\title{
The effect of firm life cycle on profitability: Evidence from Jordanian firms
}

\author{
Abdullah Aldaas ${ }^{\mathbf{a}^{*}}$ \\ ${ }^{a}$ Middle East University, Jordan \\ C H R O N I C L E

\section{Article history:} \\ Received: November 18, 2020 \\ Received in revised format: \\ December 282020 \\ Accepted: January 12, 2021 \\ Available online: \\ January 12, 2021 \\ Keywords: \\ Firm life cycle \\ Panel data \\ Financial ratios \\ Firm performance
}

\section{A B S T R A C T}

Profitability is an important performance measure and a related study based on the life cycle of firms is appreciated by researchers and managers. The impact of the financial crisis adds novelty to such research. This study discusses the impact of financial ratios on profitability of firms under the influence of financial crises. It is based on a sample of 42 Jordanian firms and uses panel data regression on an annual dataset for the time period 2000-2018. The study found mature stage firms to be explained best with the suggested model. The impact of current ratio on the profitability of all companies was observed as positive while the profitability is found to be negatively affected by debt for all life cycle stages except for the declining stage. Also, it is found that the declining stage firms need to rely on debt to stay profitable and sustain.

\section{Introduction}

Firm life cycle is a concept derived and similar to product life cycle, originally used in marketing and strategy but also used in financial studies (Yan \& Zhao,2010). A firm's life cycle is a combination of the life cycle of the products and services it offers but since these product offerings may be located in different life cycle stages, it becomes difficult to draw and capture the life cycle of a firm. Chandler (1962) proposed that a firm evolves through various stages which can be inferred as a life cycle of the firm. There are unique firm level factors (such as product portfolio) operating at different life cycle stages and then there are common industry level factors which are equally applicable to an industry or market. Each life cycle stage of a firm is unique and multifaceted (Miller \& Friesen,1984). Gort and Klepper (1982) suggested that firms follow five different life cycle stages while Miller \& Friesen (1983) found that the firms can move in a non-sequential manner across life cycle stages. Also, the duration of firms in different life cycle stages will vary across life cycle stages. Thus, because of the differences across the life cycle stages and the similarities between firms within a life cycle stage, accuracy of forecasting is a challenge for the researchers and is a serious research gap which needs to be addressed. Fairfield et al. (2009) also suggest that there is a lack of within-industry homogeneity in forecasting profitability. This corollary further highlights the importance of a firm's life cycle is studied within an industry or across industries. The number of stages suggested by different researches for the life cycle models varies from three to ten stages and all such models highlight a consistent pattern of firm development (see Adizes, 1989; Smith et al., 1985). Financial ratios are an important tool to assess the performance of a firm to enable course correction in business processes. One categorization of financial ratios classifies ratios into four segments; Profitability, Activity, Liquidity and Leverage ratios. These PALL ratios enable the researcher to look at an organization from four different perspectives. Al Daas et al. (2020) found that the value of the firm is affected by three key decisions (value drivers) of dividend, investment and financing and this effect is best measured at a lag of two years. Also, the combined effect of the three value drivers was found to be more than the standalone effect.

\footnotetext{
* Corresponding author.

E-mail address: adaas@meu.edu.jo (A. Aldaas) 
Black (1998) found that the proportion of two value drivers of a firm, assets in use and growth opportunities may vary, depending on the company's life cycle. The profitability in context to firm life cycle has been studied by Almeida et al., (2004). Warusawitharana (2013) found that growth firms are more profitable in comparison to mature firms. A study on the effect of the financial crisis on the profitability of Jordanian companies in the context of ratio-based life cycle approach is a novel study. There are very few available papers on the Middle East economy, particularly Jordon (Alzoubi, 2019) but hardly any paper was found which studies firm life cycle-based profitability of firms. Although the context is Jordan but the methodology and the learnings are applicable to other markets also. This study uses a moderated methodology derived from (Anthony \& Ramesh, 1992; Black, 1998) to contribute to the literature on the subject. Anthony \& Ramesh (1992); Black (1998) categorized the firms into different life cycle stages by considering four variables; sales growth, change in capital expenditure, annual dividend payout ratio and the firm's age. We have taken a cue from [Anthony \& Ramesh (1992); Black (1998)] and used the sales growth as the variable to categorize the 42 samples companies into five life cycle stages; introduction, growth, maturity, decline and outliers.

\section{Literature review}

A Firm life cycle needs to be studied from different perspectives, some of it already exists in literature. Gort and Klepper (1982) categorized the life cycle of firms into five stages (Introduction, Growth, Maturity, Decline, Shakeouts). The maturity and growth stage has been well studied in literature (such as Tariq et al.,2019) but the decline stage is comparative less studied. Also, performance evaluation of firms using financial ratios have been studied extensively in literature (such as La Rocca et al.,2011). Similarly, a firm life cycle has also been studied from different perspectives (Yan \& Zhao, 2010). Dickinson (2011) found that the differences in average profitability across the life cycle stages are substantial and persistent. Anthony \& Ramesh (1992) conducted one of the initial studies to demonstrate the usefulness of firm life cycle in explaining market performance. They used financial variables such as sales growth, dividend payout, capital expenditures, and firm. Firm life cycle studied in various organization context includes prediction of organizational behavior (Miller \& Friesen 1984), international human resource management practices (Milliman, Von Glinow \& Nathan,1991), evaluating organizational effectiveness (Quinn \& Cameron, 1983; Koberg, Uhlenbruck \& Sarason, 1996) found that to facilitate innovation, organizations at different stages of development require different organizational structures, focus of various stakeholder groups (Jawahar \& McLaughlin, 2001), problems faced by managers (Kazanjian, 1988), and top-management priorities (Smith, Mitchell \&Summer, 1985).

Faff et al. (2016) assert that a firm's investment, financing, and cash policies are interlinked and changes in line with its life cycle. Adizes (1979) analyzed R\&D behaviors of firms at different organizational life cycle stages. Kwon and Moon (2009) examined the return on equity (ROE) and profitability in the context of FLC and found usefulness of profitability at growth stage are lower than those at mature stage. Some other relevant previous studies on the subject includes a study of the correlations between life cycle stages with the characteristics of firms (De Angelo et al., 2006), capital structure (Owen \& Yansom, 2010); growth opportunity (Fama \& French, 2001), profitability (Warusawitharana, 2013). The 'Introduction' stage in the life cycle of a firm is the stage where innovation is commercialized and business opportunities exploited. This stage is characterized by low investments in assets, new production processes with high business risk and high borrowing costs. Managerial optimism derives investment at this stage (Jovanovic1982). The 'Growth' stage is explained as the stage when a firm starts to grow in business, profits start coming and investment increases at and financing happens through reinvestment. Growth firms increase debt (Spence, 1977). The 'Maturity' stage is recognized as the optimization of the production process with earnings expectations at highest. Depreciation finance capital investments at this stage. Also, Myers (1977) and Jensen (1986) found that at this stage the firms focus more on servicing debt and distributing profits. The 'Decline' stage is normally characterized by falling sales, declining earnings and increase in unutilized production capacity.

There have been several previous researches which have studied accounting ratios in context to firm life cycle stages. La Rocca et al. (2011) found that contrary to the conventional rationale, debt is significant in the early stages of firms, being the preferred choice of financing. Bulan et al. (2007) found that the firms initiate dividends after reaching a maturity stage in their life cycles. Mueller (1998) found that the smaller firms earn more than their cost of capital while the contrary is true for mature firms. Hasan et al., (2015) studied firm life cycles and the cost of equity and found that the cost of equity is higher in the introduction and decline stages and lower in the growth and mature stages.

Yoo et al., (2019) studied research and development expenditures in the context of FLC. Wang et al., (2020) studied working capital, firm performance and FLC and found that WCM is negatively associated with firm performance but this finding does not hold for the entire life cycle of the firm. Alzoubi (2019) did a study on Jordan firms and found that during the introduction and growth stages, cash holding decisions are irrelevant, while during the maturity and decline stages, cash holding becomes significantly negatively related. The profitability in context to firm life cycle has been studied by Almeida et al., (2004). Warusawitharana (2013) found that growth firms are more profitable in comparison to mature firms. Asset turnover ratio (ATO) as a measure of asset efficiency has been studied by Yoo et al. (2019). Liquidity in the context of firm life cycle is studied by Wang et al. (2020) and Alzoubi (2019). Various studies (La Rocca et al., 2011; Opler et al., 1999) have studied debt levels in context of firm life cycle. 


\section{Research methodology}

The objective of the study is to analyze profitability in the context of the firm life cycle with a control for the financial crisis of 2008. Anthony and Ramesh (1992) and Black (1998) categorized the firms into different life cycle stages by considering four variables; sales growth, change in capital expenditure, annual dividend payout ratio and the firm's age. We have taken a cue from (Anthony \& Ramesh, 1992; Black, 1998) and used the sales growth as the variable to categorize the 42 samples companies into five life cycle stages; introduction, growth, maturity, decline and outliers. We considered average sales growth to incorporate the effect of volatility in sales growth (See Table 1).

Table 1

The age and sales growth of sample companies

\begin{tabular}{|c|c|c|c|}
\hline Sl.No. & Company & Age (years) & Sales Growth (\%) \\
\hline 1 & The Industrial Commercial \& Agricultural & 56 & 29.26 \\
\hline 2 & Premier Business And Projects Co. Ltd & 47 & -11.59 \\
\hline 3 & Jordan Chemical Industries & 40 & -0.16 \\
\hline 4 & National Chlorine Industries & 29 & 10.79 \\
\hline 5 & Jordan Industrial Resources & 23 & 5.84 \\
\hline 6 & Comprehensive Multiple Project Company & 26 & 35.40 \\
\hline 7 & National Cable \& Wire Manufacturing & 37 & 5.74 \\
\hline 8 & Arab Electrical Industries & 37 & 6.79 \\
\hline 9 & The Jordan Pipes Manufacturing & 52 & -2.46 \\
\hline 10 & Jordan Wood Industries / Jwico & 45 & 6.29 \\
\hline 11 & Ready Mix Concrte And Construction Supplies & 25 & 8.94 \\
\hline 12 & Arabian Steel Pipes Manufacturing & 37 & 2.10 \\
\hline 13 & Jordan Poultry Processing \& Marketing & 33 & 10.94 \\
\hline 14 & Jordan Dairy & 52 & 6.58 \\
\hline 15 & General Investment & 48 & 6.96 \\
\hline 16 & Al-Qaria Food \& Vegetable Oil Industries & 27 & 4.11 \\
\hline 17 & Universal Modern Industries & 31 & 2.50 \\
\hline 18 & National Poultry & 26 & 4.85 \\
\hline 19 & The Arab International Food Factories & 26 & 471.47 \\
\hline 20 & Nutri Dar & 26 & 20.65 \\
\hline 21 & Jordan Vegetable Oil Industries & 67 & -3.32 \\
\hline 22 & General Mining Company Plc & 47 & -4.15 \\
\hline 23 & Arab Aluminium Industry /Aral & 44 & 3.72 \\
\hline 24 & National Steel Industry & 41 & 2428.05 \\
\hline 25 & Jordan Phosphate Mines & 67 & 11.97 \\
\hline 26 & The Jordan Cement Factories & 42 & -0.26 \\
\hline 27 & The Arab Potash & 22 & 11.94 \\
\hline 28 & Jordan Steel & 38 & 8.63 \\
\hline 29 & National Aluminium Industrial & 26 & 4.61 \\
\hline 30 & International Silica Industrial & 23 & 13.52 \\
\hline 31 & Travertine Company Ltd & 21 & 62.79 \\
\hline 32 & Arab Company For Investment Projects & 41 & -12.83 \\
\hline 33 & Pearl- Sanitary Paper Converting & 25 & -11.78 \\
\hline 34 & Dar Al Dawa Development \& Investment & 45 & 5.95 \\
\hline 35 & Arab Center For Pharm.\& Chemicals & 37 & -10.78 \\
\hline 36 & Middle East Pharma. & 27 & 12.70 \\
\hline 37 & Al-Ekbal Printing And Packaging & 26 & 0.50 \\
\hline 38 & The Jordan Worsted Mills & 56 & -1.55 \\
\hline 39 & Akary For Industries And Real Estate Investments & 59 & 2.42 \\
\hline 40 & El-Zay Ready Wear Manufacturing & 28 & 4.42 \\
\hline 41 & Al-Eqbal Investment Company Ltd & 28 & 12.69 \\
\hline 42 & Union Tobacco \& Cigarette Industries & 27 & -4.01 \\
\hline
\end{tabular}

Firms were categorized into five life cycle stages based on the sales growth. The average sales growth for the time period (2000-2018) was sorted in ascending order for all the 42 companies. This was subsequently divided into four quartiles and life cycle stages (see Table 3). The firms indicating negative average sales growth are categorized as outliers. The study variables used are explained in Table 2 where Net Profit Margin is used as a proxy for profitability as it is a final outcome of a firm's performance (used in Warusawitharana, 2013; Ahmad \& Murray, 2019). Current ratio is used as a proxy for liquidity (studied in Alzoubi, 2019), debt ratio is used as a proxy for leverage (as in La Rocca et al., 2011), Return on Net worth (RoNW) is used as a proxy for shareholder's profitability while Asset Turnover ratio (ATO) is used as a proxy for operational efficiency of the firm (as in Yoo et al., 2019; Hannan \& Freeman, 1984). Alzoubi (2019) did a similar study on Jordan firms with a focus on cash holdings. In this research we focus on the all the four critical areas of a firm. Perenyi et al. (2011) studied the life cycle of SMEs and found that there are outliers in these stages. Thus, five life cycle stages are used in the research (Introduction, Growth, Maturity, Decline and Outliers) as explained in Table 3. The study uses annual data from Jordanian companies for the time period 2000-2018 for five financial variables (Table 2) focusing on the four critical functions of a 
commercial organization; profitability, activity, liquidity and leverage. The data was extracted from Amman Stock Exchange, Jordan (www.ase.com.jo/en) and analyzed using the software Eviews, version 11.

Table 2

Variables used in the study

\begin{tabular}{|c|c|c|c|c|}
\hline Variables & Code & used as & Formulae & Nature \\
\hline Net Profit Margin & NPM & $\%$ & Income/Sales & Dependent \\
\hline Return on Net Worth & RoNW & $\%$ & Income/(Share capital + Total reserves) & Independent \\
\hline Assets Turnover Ratio & ATO & $\%$ & Sales/Total Assets & Independent \\
\hline Current Ratio & $\mathrm{CR}$ & $\%$ & Current Liabilities/Current Assets & Independent \\
\hline Debt Ratio & Debt ratio & $\%$ & Debt/(Debt + Equity) & Independent \\
\hline Dummy variable & Dummy & 0 or 1 & 0 for pre 2008 and 1 for post 2007 & Independent \\
\hline
\end{tabular}

Table 3

Firm categorization into life cycle stages

\begin{tabular}{cccc}
\hline Quadrant & Sales growth (\%) & Life cycle stage & \\
& Quadrant 1 & $0-4.42$ & Introduction \\
& & $4.61-6.79$ & Decline \\
& & $6.96-12.69$ & Maturity \\
Quadrant 2 & $12.7-2428$ & Growth & Outliers \\
\hline Quadrant 4 & &
\end{tabular}

The analysis includes descriptive analysis and Fixed Effect/Random Effect regression analysis. To analyze for fixed effects or random effects in panels Hausman test (Null hypothesis: Random effect is appropriate) was used. The sample companies were categorized into life cycle stages using the data for the year 2018 (Table 3). Thus, six panels were created for analysis, one for the companies' combined and one each for five life cycle stages. For each of the panel, descriptive analysis, Pooled Ordinary Least Squared (POLS) regression and fixed effect/random effect-based regression is applied for analysis. For each of the panels, Net Profit Margin (NPM) is used as dependent variable and other variables are used as independent variables (Table 2). One dummy variable is used to control for pre- and post-2008 time period. Crisis dummy is used with 0 representing before crisis period (2000-2007) and 1 representing after crisis period (2008-2018) which can be interpreted by substituting 0 or 1 into the regression equations. The R-squared values have been used to analyze regression as used in Black (1998). The panel equation is used as Eq. (1).

$$
\text { Profitability }=f\left(X_{j, t, i}\right)
$$

Here,

$j=$ number of companies as cross sections

$t=$ year $(2000-2018)$

$i=$ independent variables

The profitability model for each life cycle stage is used as Eq. (2).

$$
N P M=\beta_{0}+\beta_{1} \times A T O+\beta_{2} \times C R+\beta_{3} \times \text { Debt ratio }+\beta_{4} \times R o N W+\beta_{5} \times D U M M Y
$$

Table 2 indicates the list of sample companies, the age of the sample firms and their average sales growth. Here, the age (years) is calculated as the difference between the year 2020 (current year) and the year of incorporation of the firm. The average sales growth (2000-2018) for the sample companies is observed to vary from $-12.83 \%$ to $2428 \%$.

\section{Data Analysis and Discussions}

Evidence in literature suggests that firms within a life cycle stage have similar characteristics. Porter (1979) found considerable within-industry differences for firms' strategic choices while Miller \& Friesen (1984) found evidence of within-life cycle commonalities in firms' strategic and organizational design choices. We tried to analyze within life cycle commonalities through coefficient of variation (CV) and indicated it in Table 4. Analyzing, Table 4, the descriptive statistics for all the 42 sample companies can be considered as industry benchmarks (industry averages) to be used for comparison with the companies in different life cycle stages. The net profit margin for the industry is found negative $(-12 \%)$ with high variation $(\mathrm{CV}=-$ $30 \%)$ indicating high volatility in profits for the industry. This volatility was found lowest $(\mathrm{CV}=1.5 \%)$ for maturity stage companies which also indicated a positive net profit margin $(10 \%)$. The industry average for asset efficiency (measured by ATO ) was found at $62 \%$ while the introduction stage $(\mathrm{ATO}=77 \%)$, maturity stage $(\mathrm{ATO}=70 \%)$ and declining stage companies $(\mathrm{ATO}=71 \%$ ) indicated better asset efficiency than the industry. The liquidity for all stage companies (except $\mathrm{CR}=1.81$ for mature companies) was found satisfactory $(\mathrm{CR}>2)$. The debt ratio for all life cycle stage companies, including industry, was observed at similar levels. The return on net worth (RoNW) was observed positive for all groups (except growth stage companies), including the industry. The mature stage companies are observed to perform best while the growth stage companies 
were observed to perform worst in terms of profitability (NPM and RoNW). This was further explained by a positive crisis dummy independent variable in panel 3 (Eq. (5)). It was observed that for some of the growth stage companies the profitability was poor in the pre-2008 (pre financial crisis) time period which brought down the average NPM and average RoNW to negative levels.

Table 4

Descriptive statistics for various growth stages

\begin{tabular}{|c|c|c|c|c|c|}
\hline \multicolumn{6}{|c|}{ Introduction } \\
\hline & NPM & ATO & $\mathrm{CR}$ & Debt Ratio & RoNW \\
\hline Mean & -0.11 & 0.77 & 3.29 & 0.34 & 0.01 \\
\hline $\mathrm{CV}$ & -12.67 & 0.58 & 0.85 & 0.94 & 12.92 \\
\hline \multicolumn{6}{|c|}{ Growth } \\
\hline & NPM & ATO & $\mathrm{CR}$ & Debt Ratio & RoNW \\
\hline Mean & -0.20 & 0.49 & 3.50 & 0.35 & -0.02 \\
\hline $\mathrm{CV}$ & -7.17 & 0.95 & 3.87 & 0.90 & -8.90 \\
\hline \multicolumn{6}{|c|}{ Maturity } \\
\hline & NPM & ATO & $\mathrm{CR}$ & Debt Ratio & RoNW \\
\hline Mean & 0.10 & 0.70 & 1.81 & 0.35 & 0.17 \\
\hline $\mathrm{CV}$ & 1.48 & 0.47 & 0.90 & 0.60 & 1.82 \\
\hline \multicolumn{6}{|c|}{ Decline } \\
\hline & NPM & ATO & $\mathrm{CR}$ & Debt Ratio & RoNW \\
\hline Mean & -0.01 & 0.71 & 2.15 & 0.29 & 0.04 \\
\hline $\mathrm{CV}$ & -17.84 & 0.45 & 0.51 & 0.44 & 3.02 \\
\hline \multicolumn{6}{|c|}{ Outliers } \\
\hline & NPM & ATO & $\mathrm{CR}$ & Debt Ratio & RoNW \\
\hline Mean & -0.33 & 0.52 & 2.52 & 0.35 & 0.06 \\
\hline $\mathrm{CV}$ & -21.62 & 0.81 & 0.90 & 0.65 & 3.20 \\
\hline \multicolumn{6}{|c|}{ Combined } \\
\hline & NPM & ATO & $\mathrm{CR}$ & Debt Ratio & RoNW \\
\hline Mean & -0.12 & 0.62 & 2.62 & 0.34 & 0.05 \\
\hline $\mathrm{CV}$ & -30.05 & 0.66 & 2.36 & 0.74 & 3.71 \\
\hline
\end{tabular}

Panel regressions

Panel 1: A panel OLS regression for all 42 sample companies indicated that fixed effects are more appropriate for this panel (Hausman test $\mathrm{p}$-value $=0.009$ ). The fixed effect panel regression model (equation 3 ) was found significant $(\mathrm{p}$-value $=0.005$, R-squared at 9.6\%) along with the independent variables, RoNW and debt ratio significant at 1\% confidence level.

$$
N P M=0.59+0.41 \times A T O+0.003 \times C R-3.40 \times \text { debt ratio }+2.24 \times R o N W+0.11 \times D U M M Y
$$

Panel 2: A panel OLS regression for the 'introduction' stage companies indicated that fixed effects are more appropriate for this panel (Hausman test $\mathrm{p}$-value=0.02). The fixed effect panel regression model (equation 4) was found significant ( $\mathrm{p}$ value $=0.001$, R-squared at $22.31 \%$ ) along with the independent variables ATO found significant at $1 \%$ confidence and the dummy variable found significant at $10 \%$ confidence level.

$$
N P M=-0.92+1.71 \times A T O-0.02 \times C R-0.59 \times \text { debt ratio }+0.50 \times R o N W-0.53 \times D U M M Y
$$

Panel 3: A panel OLS regression was conducted for 'growth' companies and the Hausman test ( $p$-value $=0.95)$ indicated that random effects are more appropriate for this panel. A random effect panel regression model (equation 5) was found significant ( $\mathrm{p}$-value $=0.0$, R-squared at $21.78 \%$ ) along with the independent variables ATO found significant at $10 \%$ confidence level while debt ratio and RoNW found significant at $1 \%$ confidence level.

$$
N P M=0.27+0.45 \times A T O-0.04 \times C R-1.63 \times \text { debt ratio }+2.29 \times R o N W+0.11 \times D U M M Y
$$

Panel 4: A panel OLS regression was conducted for 'mature' stage companies and the Hausman test $(\mathrm{p}$-value $=0.63)$ indicated that random effects are more appropriate for this panel. A random effect panel regression model (equation 6) was found significant ( $\mathrm{p}$-value $=0.0, \mathrm{R}$-squared at $74.33 \%$ ) along with the all independent variables found significant at $1 \%$ confidence level.

$$
N P M=0.12-0.06 \times A T O+0.011 \times C R-0.11 \times \text { debt ratio }+0.37 \times R o N W-0.043 \times D U M M Y
$$

Panel 5: A panel OLS regression was conducted for 'decline' stage companies and the Hausman test ( $p$-value=1) indicated that random effects are more appropriate for this panel. A random effect panel regression model (equation 7) was found significant (p-value $=0.0, \mathrm{R}$-squared at $52.51 \%$ ) along with the independent variables, ATO and RoNW found significant at $5 \%$ confidence level.

$$
N P M=-0.28+0.14 \times A T O+0.041 \times C R+0.23 \times \text { debt ratio }+1.03 \times R o N W-0.05 \times D U M M Y
$$


Panel 6: A panel OLS regression was conducted for 'outlier' stage companies where the Hausman test (p-value=0.06) indicated that fixed effects are more appropriate for this panel. A subsequent fixed effect panel regression model (equation 8) was analyzed which found significant ( $\mathrm{p}$-value $=0.015$, R-squared at $15 \%$ ) along with the independent variables, debt ratio found significant at 5\% confidence level and RoNW found significant at 10\% confidence level.

$$
N P M=+3.29+0.39 \times A T O-0.63 \times C R-8.97 \times \text { debt ratio }+6.65 \times R o N W+1.07 \times D U M M Y
$$

The effect of financial crisis (dummy variable) on profits was observed positive and equal for the industry (r=0.11) and growth stage companies $(\mathrm{r}=0.11)$ indicating that after the financial crisis of 2008 , on an average the firms performed well and this performance was driven by growth stage companies. Profitability was explained positively by asset efficiency for all stage companies except for a minor correction for mature stage companies. The impact of current ratio on the profitability of all companies was observed as positive but low, except for outlier stage companies where this effect was high and negative ( $\mathrm{r}=-$ 0.63 ). This could also be interpreted as, if a firm has negative sales growth then there is an inverse relationship between current ratio and profits. Profitability is found to be negatively affected by debt for all life cycle stages except for the declining stage $(\mathrm{r}=0.23)$ indicating that when a firm enters the declining stage, it relies on debt to sustain in business (contrary to La Rocca et al., 2011).

\section{Conclusions}

The objective of the research is to analyze profitability of firms in different life cycle stages in the context of the financial crisis of 2008. The effect of the financial crisis on profits was observed positive and equal for the industry and growth stage companies indicating that the growth stage companies were able to negotiate the effect of the financial crisis better than the other stage companies. The industry volatility $(\mathrm{CV}=-30 \%)$ and industry averages for profits $(\mathrm{NPM}=-0.12 \%)$ was found to be a concern for Jordanian firms for the given time period. The growth stage companies were observed to perform worse in terms of profitability (NPM and RoNW) although they indicated highest sales growth over the time period (2000-2018). This could be due to negative profit levels for companies in the pre-2008 time period. The maturity stage companies were found to perform best on the profit parameter with a low volatility $(\mathrm{CV}=1.5 \%)$ and positive net profit margin $(10 \%)$. The maturity stage companies were also observed to outperform other life cycle stages and the industry on other parameters (except current ratio, $\mathrm{CR}=1.81$ ). Also, in terms of explained variance ( $\mathrm{R}$-squared values as in Black,1998), panel four (mature firms) was observed with highest R-squared values (74\%). It can be concluded that the suggested research methodology may work best for analyzing mature stage companies. Also, the firms in declining stages rely on debt to stay profitable and sustain as this is the only life cycle stage which indicates a positive debt ratio coefficient with profitability.

\subsection{Managerial and future research implications}

The impact of current ratio on the profitability of all companies was observed as positive but low except for outlier stage companies where this effect was high and negative $(\mathrm{r}=-0.63)$. This could also be interpreted as if a firm has negative sales growth then there is an inverse relationship between current ratio and profits. This is a useful finding for managers. Profitability is found to be negatively affected by debt for all life cycle stages except for the declining stage ( $\mathrm{r}=0.23)$ indicating that when a firm enters the declining stage, it relies on debt to sustain in business. Banks and debt lenders may target declining stage firms to grow their business. Out of the six panels, the panel for the mature stage companies was best fitted in terms of explained variance and indicated best average parameters. Thus, equation 6 can be used to forecast profitability with most efficiency for mature stage firms. The study could be replicated in future studies on a wider, multi country sample to further generalize the model.

\section{Acknowledgement}

The author is grateful to the Middle East University, Amman-Jordan for the financial support granted to cover the publication fee of this research article.

\section{References}

Adizes, I. (1979), Organizational passages-Diagnosing and treating lifecycle problems of organizations. Organizational Dynamics, 8(1), 3-25

Adizes, I. (1989). Corporate Lifecycles: How and Why Corporations Grow and Die and What to Do About It. Englewood Cliffs, New Jersey: Prentice Hall, 1989.

Ahmad, M.U. \& Murray, J. (2019). Understanding the connect between digitalization, sustainability and performance of an organization, International Journal of Business Excellence, 17(1), 83-96.

Al Daas, A.; Ahmad, M. U. \& Mohammad, S.J. (2020). The dynamics between dividends, financing and investments: Evidence from Jordanian companies. International Journal of Financial Research, 11(4), 231-240

Almeida, H., Campello M., \& Weisbach M. (2004). The cash flow sensitivity of cash. Journal of Finance, 59(4), $1777-1804$.

Alzoubi, T. (2019), Firms' Life Cycle Stage and Cash Holding Decisions, Academy of Accounting and Financial Studies Journal, 23(1), 1-8 
Anthony, J., \& K. Ramesh (1992). Association between accounting performance measures and stock prices: A test of the life cycle hypothesis. Journal of Accounting and Economics, 15(2-3), 203-227.

Black, E. (1998). Life-cycle impacts on the incremental value-relevance of earnings and cash flow measures. Journal of Financial Statement Analysis, 4(1), 40-56.

Bulan, L., Subramanian, N. \& Tanlu, L. (2007). On the timing of dividend initiations. Financial Management, 36(4), $31-65$.

Chandler, A.D. (1962), Strategy and Structure. MIT Press: Cambridge, MA, USA.

De Angelo, H., De Angelo, L. \& Stulz, R. (2006). Dividend policy and the earned/contributed capital mix: A test of the lifecycle theory. Journal of Financial Economics, 81(2), 227-254.

Dickinson, V. (2011). Cash flow patterns as a proxy for firm life-cycle. Accounting Review, 86, 1969-1994.

Faff, R., Kwok, W.C., Podolski, E.J., \& Wong, G.J. (2016). Do corporate policies follow a life-cycle?. Journal of Banking \& Finance, 69, 95-107.

Fama, E. \& French, K. (2001). Disappearing dividends: changing firm characteristics or lower propensity to pay?. Journal of Financial Economics, 60, 3-43.

Gort, M., \& S. Klepper (1982). Time paths in the diffusion of product innovation. Economic Journal, 92(367), 630-653.

Hannan, M., \& Freeman, J. (1984). Structural inertia and organizational change. American Sociological Review, 49(2), 149164.

Jawahar, I., \& McLaughlin, G. L. (2001). Toward a descriptive stakeholder theory: An organizational life cycle approach. Academy Of Management Review, 26(3), 397-414.

Jensen, M. (1986). The agency costs of free cash flows, corporate finance, and takeovers. American Economic Review,76 (2), 323-329.

Yoo, J., Lee, S., \& Park, S. (2019). The effect of firm life cycle on the relationship between R\&D expenditures and future performance, earnings uncertainty, and sustainable growth. Sustainability, 11(8), 2371.

Jovanovic, B. (1982). Selection and the evolution of industry. Econometrica, 50 (3), 649-670.

Kazanjian, R. K. (1988). Relation of dominant problems to stages of growth in technology-based new ventures. Academy of Management Journal, 31(2), 257-279.

Koberg, C. S., Uhlenbruck, N., \& Sarason, Y. (1996). Facilitators of organizational innovation: The role of life-cycle stage. Journal of Business Venturing, 11(2), 133-149.

Kwon, S.Y. \& Moon, B.Y. (2009). Decomposed return on equity, future profitability, and value relevance over the firm life cycle. Korean Management Review, 39, 1231-1249.

La Rocca, M., La Rocca, T. \& Cariola, A. (2011). Capital structure decisions during a firm's life cycle. Small Business Economics, 37, 107-130.

Miller, D., \& Friesen, P.H. (1984). A longitudinal study of the corporate life cycle. Management Science, 30(10), $1161-1183$.

Miller, D., \& Friesen, P. H. (1983). Successful and unsuccessful phases of the corporate life cycle. Organization studies, 4(4), 339-356.

Milliman, J., Von Glinow, M.A., \& Nathan, M. (1991). Organizational life cycles and strategic international human resource management in multinational companies: Implications for congruence theory. Academy of Management Review, 16(2), 318-339.

Mostafa, M. H., Hossain, M., Cheung, A., \& Habib, A. (2015). Corporate life cycle and cost of equity capital. Journal of Contemporary Accounting \& Economics, 11(1), 46-60.

Mueller, D. C., \& Yun, S. L. (1998). Rates of return over the firm's lifecycle. Industrial and Corporate Change, 7(2), 347368.

Myers, S. (1977). Determinants of corporate borrowing, Journal of Financial Economics, 5(2), 147-175.

Opler, T., Pinkowitz, L., Stulz, R., \& Williamson, R. (1999). The determinants and implications of corporate cash holdings. Journal of Financial Economics, 52(1), 3-46.

Owen, S. \& Yamson, A. (2010). Corporate life cycle and M\&A activity. Journal of Banking \& Finance, 34, 427-440.

Perenyi, Á., Selvarajah, C., \& Muthaly, S. (2011). Investigating the firm life-cycle theory on Australian SMEs in the ICT sector. Journal of Asia Entrepreneurship and Sustainability, 7(2), 13-51.

Porter, M. E. (1979). The structure within industries and companies' performance. The Review of Economics and Statistics, 61(2), 214-227.

Quinn, R. E., \& Cameron, K. (1983), Organizational life cycles and shifting criteria of effectiveness: Some preliminary evidence. Management Science, 29(1), 33-51.

Smith, K. G., Mitchell, T.R., \& Summer, C.E. (1985). Top level management priorities in different stages of the organizational life cycle, Academy of Management Journal, 28, 799-820.

Spence, M. (1977). Entry, capacity, investment, and oligopolistic pricing. Bell Journal of Economics, 8(2), 534-544.

Wang, Z., Akbar, M., \& Akbar, A. (2020). The Interplay between Working Capital Management and a Firm's Financial Performance across the Corporate Life Cycle. Sustainability, 12, 1661.

Warusawitharana, M. (2013). Profitability and the Lifecycle of Firms. Working paper. Board of Governors of the Federal Reserve System (available at www.federalreserve.gov/pubs/feds/2012/201263/)

Yan, Z \& Zhao, Y. (2010). A new methodology of measuring corporate life-cycle stages. International Journal of Economic Perspectives, 4(4), 579-587. 
(C) 2021 by the authors; licensee Growing Science, Canada. This is an open access article distributed under the terms and conditions of the Creative Commons Attribution (CC-BY) license (http://creativecommons.org/licenses/by/4.0/). 